\title{
China-Latin America: Economic Relations in the 21st Century. Latin American Perspective on Opportunities and Threats
}

\begin{abstract}
This article raises the issue of China-Latin America economic relations in this century. During the first two decades of the 21st century, there has been a significant increase in trade between China and Latin America, and China's investments in Latin America have increased. Although the presented text discusses the issues of economic cooperation, its primary objective, however, is not to present the dynamics of these relations, but to reflect on the chances and risks for Latin America resulting from economic cooperation between China and Latin America. The article thus discusses the area of opportunities and threats in numerous aspects, giving various arguments and numerous examples. The conclusions of the article refer both to emerging challenges and the prospects for cooperation.
\end{abstract}

Key words: China-Latin America; economic relations; opportunities for Latin America; threats for Latin America

\section{Introduction}

C hina-Latin America relations have a centuries-old history. The first confirmed contacts between the two regions were connected with the Spanish colonial expansion in Asia and resulted from the Spaniards' silk sea route, which from the 16th century led from China, through the Philippines to Central and South America. China's presence in Latin America dramatically increased in the 19th century (Eakin, 2009, p. 277; Mazza, 2016; Mazurek, 2006, pp. 25-28). At that time the first official diplomatic relations between the Empire of China and some Latin American countries began. The 20th century brought significant challenges for China-Latin America contacts. The establishment of the Republic of China (at the turn of 1911 and 1912) did not overcome the marasmus of mutual relations, and the proclamation of the People's Republic of China (1949) froze these relations for some time. They were rebuilt slowly and with obstacles in subsequent decades. In the 1980s and 1990s the cooperation was strengthened, which resulted in the intensification of contacts at the beginning of the 21st century (Rowiński, 2006, pp. 312-334).

China-Latin America relations are discussed in the literature of political science, both from a historical perspective and from the perspective of contemporary challenges. However, referring existing studies to the issues raised in this text, one should note a certain tendency. China-Latin America economic relations are usually, if not mostly, discussed by authors on the level of what Latin America gives to China. In these perspectives, Latin America is often analysed as an economically underdeveloped partner which, thanks to China, has a chance to be liberated from the economic dominance of the United States. Opportunities and threats resulting from cooperation are usually presented from the point of view of China as the stronger entity in bilateral relations (cf., for 
example: Ameryka Łacińska..., 2007; Locatelli, 2011; The Political..., 2017). This text offers a change of perspective - from Chinese to Latin American. Moreover, it provides not only an analysis of profits and losses. The aim of this study is therefore to answer the question - what chances and what threats for Latin America in the 21 st century are posed by China-Latin America economic cooperation?

\section{China-Latin America economic relations in the 21st century}

During the first two decades of the 21 st century, there has been a significant increase in trade between China and Latin America (Fontdeglòria, 2015). China's investments in Latin America have also significantly increased. The ongoing economic rapprochement has largely resulted from China's policy of tightening economic relations with the most promising regions of the world (i.e. Latin America), aimed at counteracting the effects of lowering GDP growth and getting rid of the risk of falling into the middle income trap (Cieślik, 2016).

The middle income trap is connected with the economic slowdown and the threat of remaining among middle-developed countries, and the cure for it (apart from providing the raw material and product base for further development and new sales markets) is innovation and investment. This direction of the Chinese economy - aimed at halting negative economic tendencies - was reflected in the promoted paths of cooperation between China and Latin America. And although trade was still considered to be the basic pillar of China-Latin America economic relations, there was a noticeable emphasis in mutual contacts in the sphere of investment and innovation. This concept of bilateral relations was confirmed at the Forum of China and the Community of Latin American and Caribbean States of 2015. China presented a plan of cooperation with the Latin American region, setting up three levels of cooperation (trade, investment and financial market) in six priority industries (agriculture, energy and raw materials, infrastructure, processing, education with IT and technological innovations). China also announced that they would invest $\$ 250$ billion in Latin America over the next decade, and bilateral trade would rise to $\$ 500$ billion over this period (Exploring..., 2015; Skowronek, 2015). It is worth noting that the announcements of intensification of cooperation in economy were supported by the activities of organisations promoting bilateral trade contacts (including Agência Brasileira de Promoção de Exportações e Investimentos, or Apex-Brasil, Argentinian Agencia Argentina de Inversiones y Comercio Internacional, Chilean ProChile or Costa Rican Procomer). Moreover, cultural initiatives promoting mutual knowledge and cultural rapprochement between communities were of significant importance for the development of economic relations. This role was played by, for example, the Confucius Institutes operating in Latin America. The year of Chinese-Latin American cultural exchange which was inaugurated in 2016 in China also supported these relations $(2016 \ldots$, 2016; Skowronek, 2015).

Due to the importance of trade in mutual economic contacts, it is worth paying attention to the value and the commodity structure of trade between the discussed regions. At the beginning of the 21 st century, China became the second most important source of Latin American imports after the United States. China also became the third export mar- 
ket for the Latin American continent, after the United States and the European Union. For China, Latin America is primarily a source of food products (corn, soy, wheat or fish) and natural resources (including copper, nickel, iron, gas and oil). The share of industrial goods sold from Latin America to China in subsequent years was relatively small and amounted to only a few percent in overall export. In the first decades of the 21st century, Chinese exports to Latin American countries were based primarily on medium-high technology and high-technology products, industrial products and ready-made products, such as electrical appliances, computers, footwear and clothing (Cieślik, 2016; Morgan, 2017; Ray, Gallagher, 2017).

Chinese investments and loans in Latin America were important areas of economic cooperation in the 21st century between China and the Latin American region. Investments were made especially in Brazil, Peru and Argentina, and were mainly connected with the mining industry. Loans granted by China to Latin American entities went mostly to the energy sector and were spent on the construction of infrastructure. The main beneficiaries of Chinese loans included: Venezuela, Brazil, Argentina, Ecuador, Peru and Mexico (Cieślik, 2016; Dollar, 2017; Ray, Gallagher, 2017).

When analysing the sphere of trade as well as investments and loans, it should be noted that China was particularly interested in Brazil, Argentina, Chile and Venezuela, as well as Cuba, Mexico, Ecuador, Peru and Colombia. However, the strength of relations between China and individual entities was different (Liberska, 2010, pp. 331-358).

The main trading partner of the PRC in Latin America and the most important recipient of China's investments was Brazil, which was a dynamically developing regional power at the beginning of the 21st century. Brazil's diplomacy, avoiding ideological preferences in its assumptions, was focused on pragmatic activities and maximising profits, including economic and trade benefits which were to serve the development of the state and strengthen its position in Latin America, as well as in the world. Conducting its regional and global policy, Brazil tried to confirm and strengthen its status and importance. Brazil - both in the 21 st century and in previous years - places the national interest in the centre of its foreign policy, implemented through contacts with other countries regardless of their political systems and respecting the principle of non-interference in the internal affairs of these entities. Pragmatism and orientation towards the implementation of economic interests made Brazil a valuable partner in economic relations, with which numerous world economies, including China, were eager to tighten relations (Spyra, 2006a, pp. 65-71).

The China-Brazil strategic partnership was established in 1993 (Jenkins, 2012, p. 22). It became the basis for strengthening bilateral economic ties in the following years, which resulted in dynamic trade, investment and financial relations in the first decades of the 21 st century. China's share in Brazilian exports increased, while the share of the United States decreased. In this way, since 2009 China has played the role of the most important partner in Brazilian trade, taking over the position previously occupied by the United States (Guilhon Albuquerque, 2016, pp. 51-60; Łasak, 2015, pp. 55-67; Maroszek, 2009; Pereira, de Castro Neves, 2011; Toribio Dantas, Khalil Jabbour, 2016, pp. 313-322).

It is worth paying attention to the important level of cooperation between China and Brazil, namely cooperation within BRICS (and BRIC before 2011). The aim of the group 
of countries referred to as BRICS, formed by Brazil, Russia, India, China and South Africa, is to strengthen economic cooperation which will support the economic development of these states. Thus, the cooperation is to increase the dynamics of economic growth of the BRICS countries, as well as provide the group states with the possibility of greater impact on processes taking place on the international arena, which in turn means a change in the balance of power in the world. The BRICS countries are distinguished by the growth rate of their economies, and they share some features, such as a large territory with a significant number of inhabitants and an abundance of natural resources. The similarities compensate for fundamental differences in the direction of production, historical experience, running many areas of politics or organisation of society. These differences, however, do not hamper cooperation, whose dynamism and goals have been directly translated into the development of China-Brazil economic bilateral relations (Guilhon Albuquerque, 2014, pp. 108-120; Smyrgała, 2015; Witczak, 2017).

In the face of changes taking place on the international arena, the strengthening of relations between the People's Republic of China and Brazil, which took place at the beginning of the 21 st century, was the result of rapidly growing benefits from the cooperation, both in the economic and political dimensions. Both countries - looking for opportunities to increase their potential - were interested in cooperation in the fields of experience exchange and support for the development of technology, science and innovation, energy industry, mining, transport, infrastructure development, as well as investment, financial and trade cooperation and cultural exchange. In order to expand relations on these levels, in 2004 the China-Brazil High-level Coordination and Cooperation Committee was established (Comissão Sino-Brasileira de Alto Nivel de Concertação e Cooper-COSBAN), which became a significant instrument for the coordination of bilateral contacts. The Committee worked within eleven subcommittees and seven working groups responsible for particular spheres of relations. It is also worth noting that closer ties between the countries have resulted in joint ventures, such as a high-tech project on remote sensing satellites, called CBERS - China-Brazil Earth Resources Satellite (see: China ...; History).

Another country that has developed particular economic ties with China in recent decades is Argentina. This state sought in its policy (both in the 20th and 21st centuries) to normalise its internal and foreign situation and ensure conditions for functioning in a favourable external environment. Argentine diplomacy put a lot of emphasis - which is crucial - on the expansion of relations within international organisations and on rapprochement with partners important for the development of the national economy (Pereira Carrero, 2006, pp. 100-110). Despite clear economic growth over several decades (Lasak, 2015, p. 56), the economic situation of Argentina at the beginning of the 21st century was still far from stable, and periods of prosperity were interrupted by serious crises. At the turn of 2001 and 2002, Argentina experienced a currency crisis, which became a spark for serious riots in the country. After this breakdown, the economy in Argentina began to rise very quickly, with a growth rate standing out against other countries in the Latin American region. In the years 2003-2013, GDP growth amounted to 6\% on average, despite the fact that from 2008 Argentina's economy began to slow down, and in 2014 it fell into recession. The bad situation was aggravated by the fact that the price of soy, which is one of the main export products of this country, fell in international markets (Argentyna ...; Żuławska, 2003, pp. 38-48). 
So how did the economic relations of the PRC and Argentina develop? The strategic China-Argentina partnership was established in 2004. In the 21st century, China became the second trading partner for Argentina (after Brazil) and its important investor. The Argentine Republic also became one of the most important recipients of China's loans (after Venezuela and Brazil). This was important because the loans granted by the PRC were among the most important factors helping Argentina to exit the economic collapse after 2014. The crisis in Argentina, deepened by inflation, poor export levels and a shortage of foreign exchange reserves, did not stop the cooperation between the two countries, and the assistance provided by China pushed Argentina into the next period of economic growth (Argentyna ...; Maroszek, 2009; Nowak, 2016, pp. 201-212).

As has already been mentioned, apart from Brazil and Argentina, other countries of Latin America have also become important economic partners of China in that region. Chile is one of the states with dynamic relations with China. It is worth noting that Chile managed to create a stable political system as early as in the 19th century, which significantly influenced the formation and consolidation of the basic principles and objectives of its foreign policy. They were consistently - though in different conditions and sometimes with certain concessions - followed by Chilean diplomacy in subsequent centuries. In this way, in the 19th and 20th centuries, the characteristics of Chile's foreign policy were pragmatism, realism, balance and striving for supremacy. The main goals of Chile in its contacts with other countries were therefore focused on ensuring the security and integrity of Chile's territory, gaining an advantage in the region, reluctance to engage in remote, foreign conflicts, as well as defending the country's economic interests. At the turn of the 20th and 21st centuries, the foreign policy assumptions also involved support for the development of democracy in Latin America and support for mechanisms for the protection of human rights, recognised as factors ensuring stability on the continent and reducing social inequalities and poverty. The stable situation of the region began to be understood as an element conducive to integration among Latin American countries, including - particularly - its economic dimension. The economisation of foreign policy was strongly visible in the external activities of Chile, becoming even more important in the first decades of the 21 st century. The objectives of Chile's diplomacy thus included the acquisition of new markets, removal of obstacles to free trade and boosting trade exchange (Spyra, 2006b, pp. 122-136). This approach resulted in the intensification of Chile's economic contacts, and tightening economic ties with the People's Republic of China.

An important event in the economic relations between China and Chile was the signing of a free trade agreement in 2005 (it entered into force in 2006). It was the first agreement of this type between the PRC and a Latin American state. The contract brought a significant increase in bilateral trade (a decade after signing the agreement it increased almost five times), leading to deepened cooperation in various areas related to economy, including science and technology. The free trade agreement strengthened the dynamics of contacts, although it was not the only agreement signed between Chile and the People's Republic of China. After the 2005 agreement, the countries concluded a number of different types of economic agreements, including an agreement on the avoidance of double taxation and a foreign exchange swap agreement between central banks. An important step in bilateral relations was also signing an agreement on laying fibre optic 
cable in March 2016. It is worth noting that the mutual relations between China and Chile could not have been gradually strengthened if it had not been for the fact that as a result of reforms in the 20th century and economic assumptions conductive to development, Chile became the safest and most stable Latin American country, with solid macroeconomic foundations and a high rate of economic freedom, as well as a country that provided legal guarantees for foreign companies (Cieślik, 2016; Łasak, 2015, pp. 55-67; Smyrgała, 2015).

Venezuela, called the Bolivarian Republic of Venezuela after 1999, is another country worth noting in the context of the development of economic relations with China. The change of the official name was made by then president Hugo Chávez, who, making radical transformations in the internal and external policy of the country, led to a rapprochement between China and Venezuela. The assumptions of the "Bolivarian Revolution" promoted by Chávez, which involved deep reforms aimed at reducing poverty and social inequalities through multifaceted changes in politics, economy and society (see: Fijałkowska, Gawrycki, 2010), required large financial resources. Tasks planned for future and current needs meant Venezuela needed loans as well as trade income. In this way, China became a lender to the Bolivarian Republic of Venezuela, which - paying off its loan obligations - began to supply large amounts of oil to China and thus satisfy part of its high demand for this raw material. As a consequence, Venezuela became the Latin American country most indebted to China, and focused on developing contacts with China in three main areas: energy, finance and technology (Charles, 2016; Wenezuela..., 2017).

It is worth adding that both in the 20th and the 21st centuries, crude oil constituted the basic export asset of Venezuela, making the state dependent on the prices of this raw material on the international arena. The fall in oil prices recorded from 2014 led the Bolivarian Republic of Venezuela into a serious economic crisis. The significant decrease in the GDP and huge inflation resulted not only in mass social protests, but also difficulties in paying off foreign debt. All this meant that in 2017 Venezuela was on the brink of economic disaster. Importantly, the poor economic and political situation in this country, and problem of debt repayment, did not break the relations between China and Venezuela, although they changed their dynamics and the catalogue of possible benefits (Hsiang, 2017).

The above considerations show that the People's Republic of China intensified contacts with a large group of Latin American countries in the 21st century. The significant development of relations and essential economic rapprochement with some countries did not exclude the development of relations with other countries, albeit to a lesser extent. China also developed economic cooperation with Cuba (where China's investments focused on the maritime and mining sectors), Mexico (for which China became the second largest source of imports after the United States), Ecuador (which paid off China's loans with oil supplies, and where China invested in the energy sector), as well as Colombia and Peru (where China became their top partner in export and import) (Cieślik, 2016; Łasak, 2015, pp. 55-67; Marzec, 2016, p. 32; Skowronek, 2015).

The strengthening of China-Latin America economic relations which occurred in the 21 st century, should be considered as a phenomenon worth noting - from the point of view of China's economy, diversification of its international ties, the analysis of develop- 
ment opportunities, and from the perspective of new phenomena occurring in the world economy. It is also a phenomenon worth analysing from the Latin American perspective, from the perspective of opportunities and threats for Latin America and the economies of its countries. This has become the aim and main assumption of this text.

\section{Opportunities for Latin America resulting from the economic cooperation between China and Latin America in the 21st century}

One of the main opportunities for Latin America, which is seen in the cooperation of China with the countries of this continent, is an alternative to US dominance in the region. In the economic dimension, it is primarily about diversification in trade achieved by gaining new markets, which gives an opportunity for Latin American entities to increase their exports and obtain investments and loans needed to develop (China, Latin America ..., 2011, pp. 7-16).

The range of economic benefits that Latin America may gain from cooperation with the PRC is wide. There are profits which - although they concern economy - should also be considered from a political perspective. One of them is that China, realising its economic interests in Latin America, does not interfere in the internal affairs of these countries. Relations between the United States and Latin America were dominated for decades by a different approach, making Latin America a zone of direct US influence, also within the internal policies of individual countries of the continent (Cieślik, 2016; Christensen, Ramos Becard, 2016, pp. 1-9).

The source of the strong presence of the United States in the Latin American region can be found in the Monroe Doctrine (1823). The assumptions of this concept were referred to in the 19th and 20th centuries at the regional and global level, making it one of the most lasting and vital concepts in the history of international relations. The doctrine was founded on the belief of the Founding Fathers of the United States that the political system of the United States, based on democracy and the republican government, was diametrically different from any of the European countries' systems based on monarchical rule, absolutism and perpetual aggressive wars. The American and European systems were therefore considered to be different both in the foundations of their creation and in the very essence of their functioning. The Monroe Doctrine was also based on the political view that it was in the interest of the United States to avoid engaging in European disputes and, as a result, not to enter into agreements with any entity or group of entities in Europe. This approach became a concrete state position at the beginning of the 19th century. Since the creation of the Monroe Doctrine, founded on the initiative of John Quincy Adams, secretary to President James Monroe, and included in the annual president's address to Congress on 2 December 1823, it was a determinant for US foreign policy, defining the place of the US in the international order and affecting the world order over the following centuries (Dobrzycki, 2004, pp. 81-83; Włuczkowski, 2015, p. 146).

The Monroe Doctrine was to regulate the basic issues in relations between the Americas and Europe. It stated that the territory of the Americas could not be considered the subject of future European colonisation. Moreover, it claimed that any attempt to ex- 
tend the political systems of European powers to the Western Hemisphere would be considered an act of hostility toward the United States. This rejection of the policy of involvement of European entities in the Americas was supported by the announcement of the United States' non-intervention in both the affairs of European countries and their colonies. This meant renouncing any involvement in European policy (Dobrzycki, 2004, p. 83; Fatalski, 2009, p. 87; Gilderhus, 2006, pp. 5-16).

For the United States the Monroe Doctrine was a declaration of isolationism, which from then on was regarded as the official US direction, able to protect the political and territorial interests of the United States. It also became an instrument of US dominance of Latin America, placing the US in a hegemonic position in the Western Hemisphere. Being a constant point of interest for its northern neighbour, due to the Monroe Doctrine and its complement (expressed on 6 December 1904 in President Theodor Roosevelt's speech in which he granted the United States the right to intervene in Latin American countries), Latin America was in the immediate zone of US influence. And although in the 1930s the right to intervention was supplanted by a policy of good neighbourliness, the strong influence of the United States on the activities of Latin American countries did not disappear, persisting in a variety of forms in the following decades and as a derivative of subsequent doctrines present in US foreign policy (Fatalski, 2009, pp. 86-88; Włuczkowski, 2015 pp. 148, 150-151).

What was the reaction of Latin American countries to the declarations made by the United States resulting in the expansion of the sphere of US influence and their expansion in Latin America? It cannot be said that these statements and concepts were rejected firmly and unanimously, or unquestionably accepted. As far as the Monroe Doctrine is concerned, it initially received - with some exceptions - a fairly friendly reception in Latin America. There were also enthusiastic statements about it, pointing to the overtone of the declaration, proclaiming the territorial integrity of American countries and the impossibility of their colonisation, simultaneously linking both Americas with values such as freedom, democracy and the republican form of government. Latin America also noticed the practical dimension of the Monroe Doctrine, which was often perceived as a shield that could protect independent Latin American states from European aggression (Dobrzycki, 2004, pp. 83, 258-259).

It should be noted, however, that the fear of external intervention and opposition to interference (expressed, for example, in the Drago Doctrine, developed in 1902 by the Argentine politician Luis Maria Drago; it claimed that no state entity had the right to military intervention in another country in order to collect its debts) did not refer only to European countries. Concerns in many countries about the increasingly stronger position of the United States in South America were large, strengthened by periods of decline of confidence, and often resulting in colder relations. This situation was repeated in the subsequent decades of relations between Latin America and the United States, and the desire and need for close contacts with the US was mixed with hostility towards US domination in the 19th, 20th and 21st centuries. In each Latin American country, the question of relations with the United States had its own specificity, depending on the internal situation and external circumstances of the given country. Therefore, in the contacts of individual Latin American countries with the US, there are periods of closeness and stages of reluctance, and even events that could lead to the termination of relations (in the case of Cuba 
it led to their real break, and a lack of formal Cuban-American relations in the years 1964-2014) (Dobrzycki, 2004, pp. 83, 225-227, 253-254, 258-260, 685).

The above considerations show that although the temperature and dynamics of contacts between Latin America and the United States were not always the same, each of the Latin American countries was connected with the USA in some way, at some time and with some intensity - in political, economic and social relations. Thus, the emergence of a new major player in Latin America, destroying the earlier prevailing order in the continent in external relations (especially economic relations - but not only), could be perceived as an opportunity for Latin American states to counterbalance the dominant position of the United States. In this way, China's presence in Latin America was seen as a possible source of a variety of benefits for the region that resulted from the rivalry between China and the United States over trade with Latin America, related to the economic, social and political spheres. The great prospects for building strong foundations for permanent Chinese activity in Latin America were also seen in mass direct investments that were to ensure long-term ties of interests and deepen contacts, extending them to other fields of relations (Cieślik, 2016; Rowiński, 2007, pp. 99-117; Skowronek, 2015).

It is worth adding that the positive assessment of China's economic engagement in Latin America resulted not only from the emergence of new perspectives born from the formation of a counterweight to US dominance, but also from a real improvement of the trade balance and the balance of payments of many entities on the continent. The export of raw materials and food products to China led, in some Latin American countries, to periodic trade surpluses, which - despite the temporariness of the phenomenon - was perceived as an opportunity to improve the internal situation of these countries, recognising them as a time of prosperity that could result in averting social and political conflicts or initiating development. The fact that not every Latin American country was able to take advantage of the periods of prosperity in trade to achieve lasting benefits is clearly evidenced by the case of Venezuela. However, it does not change the fact that contacts with the PRC have brought Latin America not only a number of opportunities in forecasts, assumptions and hopes, but also a range of real economic benefits that can be noticed not in the future but real time (Jenkins, Dussel Peters, Mesquita Moreira, 2008, pp. 235-253; Wenezuela-Bilans...).

Other issues to consider when analysing Latin America's opportunities arising from China-Latin America contacts include the noticeable growth of the agricultural and ecological sector (which is a consequence of the willingness to satisfy the need for a large amount of food products to be exported to China), raising the general price level of exported goods due to China's increased demand, or the creation of employment resulting from investment and export, contributing to the reduction of unemployment. These issues are raised by some researchers when assessing the benefits that Latin America received from the relations with China. It is worth emphasising, however, that there are authors who undermine the role of those factors as they do not see them as long-term chances but only as short-term, elusive profits (Jenkins, Dussel Peters, Mesquita Moreira, 2008, pp. 235-253; Ray, Gallagher, Lopez, Sanborn, 2015).

The last, but not least benefit for Latin America resulting from China-Latin America cooperation should be seen in stimulating tourism. In subsequent years of the 21 st cen- 
tury, the number of tourists from China who chose Latin American destinations grew rapidly. The basis for this increase was the agreements signed between the PRC and particular countries of the region, which assumed co-operation in the tourism sector and the creation of favourable conditions for the flow of tourists (guaranteeing, among others, easier visa procedures). This area of cooperation is perceived in Latin America as particularly important to the economic development of the countries of the continent. Its significance is largely demonstrated by the efforts and initiatives taken in the region to expand and improve the tourist offer. For many Latin American countries, tourism revenues have become an important point in the budget. In Latin America there is also the awareness that the share of Chinese tourists travelling to Latin America is still small in relation to the large number of Chinese citizens travelling abroad. This fact has mobilised the governments to take more action, for example successive bilateral agreements and facilitations to promote this sector of the economy (Harris, 2015, pp. 153-190; Maroszek, 2009; Xinhua, 2017).

\section{Threats to Latin America resulting from China-Latin America economic cooperation in the 21st century}

The intensification of economic relations between the PRC and Latin American countries has become the site of many opportunities for the region of Latin America. The emergence of opportunities for progress, stabilisation and strengthening did not mean, however, that there were no threats to be analysed here. These include, as in the case of the opportunities, a wide spectrum of possibilities, covering both the catalogue of probable dangers dependent on many variables, as well as real threats and losses that may affect economic development, contributing to the pauperisation of large groups of the Latin American population.

The first threat is the decrease in the share of domestic producers in domestic markets, which is a result of the substitution of Latin American products with cheap goods imported from China. The inflow of Chinese products to the Latin American continent - whose prices were lower than the cost of their production in Latin America - became an important element of the development of China-Latin America trade in the 21st century. This led to a situation where domestic Latin American goods, which turned out to be more expensive (even at the production stage) than goods imported from China, did not have a chance to compete on the market because of their prices, and were pushed out by cheaper Chinese products. And this not only applied to high-tech goods (electronic equipment), but also medium or low-tech goods (such as clothing or toys). For this reason, the tightening of China-Latin America economic relations began to be treated by some Latin American producers as a threat to domestic industry. Therefore, with the development of relations, endangered Latin American producers began to demand government support and interventions from state authorities to protect domestic production.

Moreover, it was observed that cheap products from China were supplanting goods manufactured by Latin American producers to be sold on the US market. Producers from Mexico, Dominican Republic and Panama experienced the power of competition with China over exports to the USA the most. However, the effects of substituting domestic 
goods with Chinese ones were also experienced in countries that exported natural raw materials and food to China, which gained huge profits from closer trade with China (Łasak, 2015, pp. 62-63; Skira, 2007). A good example was Brazil, where the dynamics of development of cooperation with China divided producers into those who - benefiting from exports - supported the expansion of cooperation areas, and those who demanded that the Brazilian authorities take protective measures (Jenkins, 2012, pp. 22-23).

Another significant threat for Latin America results from the structure of trade, which perpetuates a global division of labour which is disadvantageous for Latin America. In this division, the production processes of the Latin American countries are characterised by extensive exploitation of resources and labour force, as well as low value added, based largely on monoculture (Wielgosz, 2014, p. 128). The role of the supplier of minerals and agricultural products makes individual countries of the region more exposed to changes in the international economic situation, making their economies dependent on prices of raw materials and food on global markets which are prone to fluctuations. In this way, even a slight reduction in the price of a given product may lead to collapse in a country which based its exports on it. Moreover, treating raw materials export as the foundation of economic policy often leads to failure to use other development possibilities, such as investment in the development and modernisation of production processes, or the processing of exported raw materials, so that the largest possible value added could be generated in the country. A consequence of this approach is economic recession. The phenomenon is described in the economic literature as the Dutch disease. In the context of Latin America, it should be pointed out that the processes presented refer also to this region - as a consequence of contacts with China. The improper choice of economic priorities resulting from the abundance of natural resources can be observed in Venezuela, and in many other countries in the region that neglect processing exported goods (something that China does not resign from, as it processes imported products for their further profitable exports) (Lasak, 2015, pp. 61-62).

There are also macroeconomic threats, such as economic fluctuations, inflation or the destabilisation of exchange rates, which - if they appeared in the emerging Chinese market with a not fully stable economy - would be transferred to Latin America as a result of the closer relations with China. Close economic relations with the PRC make Latin American economies more dependent on the condition of China's economy. In other words, if there is an economic slowdown in China, this situation can quickly affect Latin America, contributing to the deterioration of the economic condition of its countries. The same criticism is given to the excessive geographic concentration of Latin America's economic cooperation, which, putting the emphasis on strengthening ChinaLatin America relations, limits cooperation with other markets - especially the United States and the European Union. Thus, the region may lose an opportunity to diversify its trade relations, which would give the possibility of a certain independence from fluctuations in the economic situation of one country and which was assessed as a favourable factor countering the dominance of the USA on the continent. So there is a threat that one dominance will be replaced by another (Łasak, 2015, pp. 61-62).

Finally, a significant threat for Latin America resulting from its economic relations with China is the taking over of land, and its accumulation on a high scale. Particular concerns arise from the observation of the practice of land grabbing, consisting in the 
purchase or lease of huge areas in developing countries (in Africa, Asia, Eastern Europe and Latin America) by foreign entities (corporations, governments or national investment funds) This land - usually with a large agricultural potential (though apart from cultivated fields forests are also acquired) - is used for investments that primarily focus on food production. Land grabbing transactions often include long-term contracting of some or all of the crops from specific territories (Łukaszewicz, 2013, p. 235; Przejmowanie..., 2010).

International trade in land is not a prohibited phenomenon, nor should it automatically involve negative consequences for a state that has disposed of or leased part of its areas. For this reason, it is assumed that in order to recognise international land trade as land grabbing, it must have features of plunder, entailing immense profits for the purchasers and asymmetry of transactions resulting from the lack of legal regulations. Thus, land grabbing does not occur when it is based on equal relations and the free will of both parties, subject to the control of intra-state and international institutions. It does take place, however, when transactions occur due to a lack of legal regulations and external monitoring, which allows investors to achieve a significant advantage over the state that sells or leases the land. Therefore, land grabbing may bring enormous profits with minimal expenses to external entities from wealthy countries undergoing rapid industrialisation, or those rich in oil. It does not violate the law, but takes advantage of its imperfection or absence; it does not, however, reduce the strength of possible threats to the societies of states that sell their terrain (Eukaszewicz, 2013, pp. 225-227).

The main danger resulting from land grabbing for those parts of the developing world that have experienced the phenomenon is the threat to their food sovereignty, food security and sustainable development. Land which is leased or bought by foreign entities cannot be used to produce food for local communities. Moreover, as a result of the opportunities provided by legal provisions, the population from the areas sold or leased often suffers additional damage, as it is expropriated and deprived of sources of income. This is possible largely because the farming and herding communities of many developing countries have a habitual right of ownership of populated territories without the written property deeds that are typical of the legal systems of highly developed countries. Resettlement and the inability to produce crops for local markets often contribute to the deepening of poverty and enlargement of famine areas. The situation is not significantly affected by the fact that some displaced farmers may find employment in newly established farms as agricultural workers (Lukaszewicz, 2013, pp. 227-235; Przejmowanie..., 2010).

It is also worth mentioning that the cultivation of land and the acquisition of agricultural produce by external investors are often accompanied by taking control over basic natural resources in the areas they have occupied (such as water, wildlife, natural resources or minerals). This usually takes place in dysfunctional countries whose institutions are not capable of valuing land correctly, assessing the effects of the transaction or protecting their own interests. Another issue is that in the areas purchased or leased by investors huge monoculture crops are grown, concentrated in mechanised and efficient large-area farms. Small domestic farms are not able to compete with them, in terms of production costs and productivity, which in turn lowers the outlook for profits from the sale of goods. Moreover, investor countries often fail to comply with environmental 
standards and contribute to lowering the quality of arable land, which also affects areas not under their management (Lukaszewicz, 2013, pp. 227, 232-233; Rulli, D'Odorico, 2013, pp. 6130-6135).

How is land grabbing related to China-Latin America cooperation? It must be noted that China's investments in Latin American land are not based on illegal activities. However, this does not change the fact that people in Latin America are afraid of abuse and confidential activities harmful to local communities. For this reason, the acquisition of land in Latin America by China is often perceived as controversial, threatening the continent's food security, limiting the pool of possible profits from the sale of food and something that can easily turn into widespread land grabbing, harmful for local communities. Concerns are intensified by the awareness of China's vast experience in buying and leasing land abroad, which is perceived as an advantage in terms of formulating arrangements that are beneficial for China (Przejmowanie..., 2010; Puyana, Costantino, 2015, pp. 105-116).

In the face of the above listed threats, it is worth noting that they did not stop the development of China's land investments in Latin America. Moreover, China has become one of the main countries acquiring land in Latin America, primarily in Argentina and Colombia, but also in Bolivia, Brazil, Jamaica, Cuba, Uruguay and Paraguay. The orientation of the goods produced proves that the main goal of China's investors became the production and export of the following products to China: soy, wheat, sorghum, maize, as well as sugar and cotton. It is important that China's investments are consistent with the programmes of the Latin American governments, focused on the development of innovative agriculture. This happened in the Argentine Republic and the Republic of Colombia, where China's investments in land increased significantly after 2008. The increase in this type of transaction does not mean, however, that there are no opponents of land acquisition in Latin America by foreign entities. This issue still evokes extreme emotions (Puyana, Costantino, 2015, pp. 105-116).

\section{Conclusions, challenges and prospects}

Summing up, it should be noted that the economic cooperation between China and Latin America brings - for the countries of the Latin American continent - both opportunities and threats, giving hope and fears. In addition, cooperation in the economic area is strongly connected with the political and social levels, which is reflected in the benefits expected by the society or projected losses. The strong dependence between economy, politics and social relations means that the Latin American political and economic elites face a challenge manifested as the inevitable need to overcome emerging problems and minimise the socio-economic threats that result from cooperation with China. These problems - regarding a wide group of Latin American communities, small entrepreneurs and farmers - cannot be hidden by the vision of benefits and growing opportunities for the region. This is because social peace and sustainable development depend on it. Moreover, the main challenges for the decision-makers of Latin American countries include in particular the need to avoid the trap of remaining only the resource base for China and the world. In order to protect themselves against it, individual Latin American entities 
should make the effort to restructure their production in order to develop branches that are complementary to Chinese industry. In this way, they will be able to compete with China - especially in markets where they have the advantage of distance (which counts in the case of speed of delivery and the ability to transport goods). It involves large investments, thus the above solution can only be considered in the long-term perspective (cf. Maroszek, 2009). It is also worth noting here that the dynamics of closer relations and mutual declarations allow one to expect that the relations between China and Latin America will be closer and more intense. In this approach, it is becoming increasingly important for Latin America - with the simultaneous awareness of the benefits - to solve the emerging problems in order to dispel any resulting fears.

\section{Bibliography}

2016, el año de América Latina (2016), 03.03.2016, China Hoy, http://www.chinatoday.mx/cul/ CLACE/content/2016-03/03/content_714790.htm, 14.01.2018.

Ameryka Łacińska w Regionie Azji i Pacyfiku (2007), ed. M. F. Gawrycki, Wydawnictwo Adam Marszałek, Toruń.

Argentyna - informacje o kraju, Informator Ekonomiczny Ministerstwa Spraw Zagranicznych, http:// www.informatorekonomiczny.msz.gov.pl/pl/ameryka_poludniowa/argentyna/, 22.01.2018.

Charles J. (2016), Venezuela and China Advance Socio-Economic Cooperation, 04.10.2016, Venezuelanalysis.com, https://venezuelanalysis.com/news/12707, 10.02.2018.

China and Brazil, Ministry of Foreign Affairs of the People's Republic of China, http://www.fmprc.gov.cn/mfa_eng/wjb_663304/zzjg_663340/ldmzs_664952/gjlb_664956/3473_665008/, 20.01.2018.

China, Latin America, and the United States: The New Triangle (2011), eds. C. J. Arnson, J. Davidow, Woodrow Wilson International Center for Scholars, Institute of the Americas, Chinese Academy of Social Sciences, https://www.wilsoncenter.org/sites/default/files/LAP_120810_Triangle_rpt.pdf, 20.02.2018.

Christensen S. F., Ramos Becard D. S. (2016), China-Latin America Relations: Main Themes, Main Problems, "Journal of China and International Relations. Special Issue: China - Latin America Relations in an Era of Changing World Order", https://journals.aau.dk/index.php/jcir/article/ viewFile/1586/1286, 21.02.2018.

Cieślik E. (2016), Tango z Pekinem. Co da Chinom wspótpraca z Ameryka Łacińską?, 15.04.2016, forsal.pl, http://forsal.pl/artykuly/935188, tango-z-pekinem-co-da-chinom-wspolpraca-z-ameryka-lacinska.html, 14.01.2018.

Dobrzycki W. (2004), Historia stosunków międzynarodowych 1815-1945, Wydawnictwo Naukowe SCHOLAR, Warszawa.

Dollar D. (2017), China's Investment in Latin America, Geoeconomics and Global Issues, Paper 4, https://www.brookings.edu/wp-content/uploads/2017/01/fp_201701_china_investment_lat_ am.pdf, 16.01.2018.

Eakin M. (2009), Historia Ameryki Łacińskiej. Zderzenie kultur, Wydawnictwo Uniwersytetu Jagiellońskiego, Kraków.

Exploring opportunities for cooperation on trade and investment (2015), First Forum of China and the Community of Latin American and Caribbean States (CELAC), https://repositorio.cepal.org/ bitstream/handle/11362/37578/S1421103_en.pdf, 14.01.2018.

Fatalski M. (2009), Doktryna Manna. Wokót założeń polityki Stanów Zjednoczonych wobec Ameryki Eacińskiej w latach sześćdziesiatych XX wieku, in: Amerykomania. Księga jubileuszowa ofiaro- 
wana Profesorowi Andrzejowi Mani, t. 1, eds. W. Bernacki, A. Walaszek, Wydawnictwo Uniwersytetu Jagiellońskiego, Kraków.

Fijałkowska A., Gawrycki M. F. (2010), Wenezuela w procesie (r)ewolucyjnych przemian, Wydawnictwo Naukowe SCHOLAR, Warszawa.

Fontdeglòria X. (2015), China se afianza en América, 07.01.2015, "El País", https://elpais.com/ internacional/2015/01/06/actualidad/1420584648_865524.html, 14.01.2018.

Gilderhus M. T., The Monroe Doctrine: Meanings and Implications, "Presidential Studies Quarterly", vol. 36 , no. 1 .

Guilhon Albuquerque J. A. (2014), Brazil, China, US: a triangular relation?, "Revista Brasileira de Política Internacional", vol. 57.

Guilhon Albuquerque J. A. (2016), Brazil/China Partnership and the United States, "Revista Tempo do Mundo", vol. 2, no. 2.

Harris R. L. (2015), China's Relations with the Latin American and Caribbean Countries. A Peaceful Panda Bear instead of a Roaring Dragon, "Latin American Perspectives", vol. 42, no. 6.

History, CBERS. National Institute for Space Research, http:/www.cbers.inpe.br/ingles/satellites/ history.php, 20.01.2018.

Hsiang A. C. (2017), China and the Venezuela Crisis, 24.07.2017, The Diplomat, https://thediplomat. com/2017/07/china-and-the-venezuela-crisis/, 11.02.2018.

Jenkins R. (2012), China and Brazil: Economic Impacts of a Growing Relationship, "Journal of Current Chinese Affairs", vol. 41, no. 1.

Jenkins R., Dussel Peters E., Mesquita Moreira M. (2008), The Impact of China on Latin America and the Caribbean, "World Development", vol. 36, no. 2.

Łasak P. (2015), Perspektywy wspótpracy handlowej Ameryki Łacińskiej z Chinami, "Studia Ekonomiczne". Zeszyty Naukowe Uniwersytetu Ekonomicznego w Katowicach, no. 226.

Liberska B. (2010), Perspektywy rozwojowe chińskiej gospodarki do 2050 roku, "Studia Ekonomiczne", vol. 67, no. 4.

Locatelli N. (2011), China in Latin America: Political and Economic Implications of Beijing's Involvement In the Region, Dissertation.com, Boca Raton.

Łukaszewicz A. (2013), Proceder grabieży ziemi jako przejaw dysfunkcyjności państwa, in: Państwa dysfunkcyjne $i$ ich destabilizujacy wpływ na stosunki międzynarodowe, ed. R. Kłosowicz, Wydawnictwo Uniwersytetu Jagiellońskiego, Kraków.

Maroszek M. (2009), Relacje Chińskiej Republiki Ludowej z Ameryka Lacińska, 28.08.2009, Portal Spraw Zagranicznych, http://www.psz.pl/117-polityka/marcin-maroszek-relacje-chinskiej-republiki-ludowej-z-ameryka-lacinska, 18.01.2018.

Marzec P. (2016), Aktualny stan stosunków Chin z Ameryka Lacińska i ich perspektywy, in: Chiny $i$ świat zewnętrzny, ed. J. Marszałek-Kawa, Wydawnictwo Adam Marszałek, Torun.

Mazurek J. (2006), Kraj a emigracja. Ruch ludowy wobec wychodźstwa chłopskiego do krajów Ameryki Łacińskiej (do 1939 roku), Muzeum Historii Polskiego Ruchu Ludowego, Warszawa.

Mazza J. (2016), Chinese Migration to Latin America and the Caribbean, The Dialogue: Leadership for the Americas, http://www.thedialogue.org/wp-content/uploads/2016/10/Chinese_Migration_to_LAC_Mazza-1.pdf, 10.01.2018.

Morgan D. E. (2017), Trade Developments in Latin America and the Caribbean, International Money Fund, https://www.imf.org/ /media/Files/.../CR/2017/cr1766-ap-5.ashx, 16.01.2018.

Nowak W. (2016), Ekspansja handlowa azjatyckich gigantów w Ameryce Łacińskiej, "Finanse, Rynki Finansowe, Ubezpieczenia", vol. 81, no. 3.

Pereira C., de Castro Neves J. A. (2011), Brazil and China: South-South Partnership or North-South Competition?, Policy Paper, no. 26, https://www.brookings.edu/wp-content/uploads/2016/ 06/03_brazil_china_pereira.pdf, 18.01.2018. 
Pereira Carrero R. (2006), Polityka zagraniczna Argentyny, in: Polityka zagraniczna państw Ameryki Łacińskiej, ed. M. F. Gawrycki, Wydawnictwa Uniwersytetu Warszawskiego, Warszawa.

Przejmowanie ziemi uprawnej w krajach rozwijajacych się godzi w ich bezpieczeństwo żywnościowe (2010), Food \& Water Europe, http://globalnepoludnie.pl/IMG/pdf/LandGrabsPolish.pdf, 03.03.2018.

Puyana A., Costantino A. (2015), Chinese Land Grabbing in Argentina and Colombia, "Latin American Perspectives", vol. 42, no. 6 .

Ray R., Gallagher K. P. (2017), China-Latin America Economic Bulletin, Global Economic Governance Initiative, https://www.bu.edu/pardeeschool/files/2014/11/Economic-Bulletin.16-17Bulletin.Draft_pdf, 16.01.2018.

Ray R., Gallagher K. P., Lopez A., Sanborn C. (2015), China in Latin America: Lessons for South-South Cooperation and Sustainable Development, Global Economic Governance Initiative, https:// www.bu.edu/pardeeschool/files/2014/12/Working-Group-Final-Report.pdf, 24.02.2018.

Rowiński J. (2006), Stosunki Chin z Ameryka Łacińska, in: Ameryka Łacińska we wspótczesnym świecie, ed. M. F. Gawrycki, Wydawnictwa Uniwersytetu Warszawskiego, Warszawa.

Rowiński J. (2007), Chiny-Ameryka Łacińska: szanse i wyzwania na progu XXI wieku, in: Ameryka Łacińska w Regionie Azji i Pacyfiku, ed. M. F. Gawrycki, Wydawnictwo Adam Marszałek, Toruń.

Rulli M. C., D’Odorico P. (2013), The water footprint of land grabbing, “Geophysical Research Letters", vol. 40, no. 23.

Skira M. (2007), China and Latin America: A Match Made in Trade Heaven or Dependency Reloaded?, Senior Honors Projects, vol. 37, http://digitalcommons.uri.edu/cgi/viewcontent.cgi?article= $1037 \&$ context $=$ srhonorsprog, 25.02.2018.

Skowronek T. (2015), Chińska hegemonia w Ameryce Eacińskiej?, 18.03.2015, Portal Geopolityka. org, http://www.geopolityka.org/analizy/tomasz-skowronek-chinska-hegemonia-w-amerycelacinskiej, 14.01.2018.

Smyrgała D. (2015), Europa oferuje Latynosom dialog, Chiny - kapitat, 26.06.2015, Obserwator Finansowy, https://www.obserwatorfinansowy.pl/tematyka/makroekonomia/europa-oferujelatynosom-dialog-chiny-kapital/, 18.01.2018.

Spyra J. (2006a), Polityka zagraniczna Brazylii, in: Polityka zagraniczna państw Ameryki Łacińskiej, ed. M. F. Gawrycki, Wydawnictwa Uniwersytetu Warszawskiego, Warszawa.

Spyra J. (2006b), Polityka zagraniczna Chile, in: Polityka zagraniczna państw Ameryki Łacińskiej, ed. M. F. Gawrycki, Wydawnictwa Uniwersytetu Warszawskiego, Warszawa.

The Political Economy of China-Latin America Relations in the New Millennium. Brave New World (2017), eds. M. Myers, C. Wise, Routledge, New York-London.

Toribio Dantas A., Khalil Jabbour E. M. (2016), Brazil and China: an Assessment of Recent Trade Relations, "Economics of Agriculture", vol. 63, no. 1.

Wenezuela - Bilans Handlowy - Prognozy, Trading Economics, https://pl.tradingeconomics.com/ venezuela/balance-of-trade/forecast, 24.02.2018.

Wenezuela bankrutem. Jest decyzja agencji ratingowej Standard \& Poor's (2017), 14.11.2017, Business Insider Polska, https://businessinsider.com.pl/finanse/makroekonomia/bankructwo-wenezuelidecyzja-agencji-ratingowej-sandp/9wxzs4r, 10.02.2018.

Wielgosz P. (2014), Rozwój albo zysk - kryzys globalizacji czy globalizacja kryzysu?, in: Afirmacja czy kontestacja? Dylemat społeczeństwa kapitalistycznego w kryzysie, eds. Z. Galor, R. Miński, P. Sałustowicz, Societas Pars Mundi Publishing, Bielefeld.

Witczak A. (2017), Państwa BRICS - motor nowego stulecia?, 02.01.2017, Finweb.pl, http://www. finweb.pl/edukacja/inne/22465-panstwa-brics-motor-nowego-stulecia, 20.01.2018.

Włuczkowski P. (2015), Izolacjonizm a izolacjonizm amerykański. Wyróżnienie pojęciowe na podstawie analizy polityki zagranicznej USA na tle historycznym, "Academic Journal of Modern Philology", vol. 4. 
Xinhua (2017), Brazil and Argentina team up to attract Chinese tourists, 09.11.2017, China Daily, http://www.chinadaily.com.cn/travel/2017-11/09/content_34309209.htm, 24.02.2018.

Żuławska U. (2003), Argentyński kryzys walutowy-geneza, "Bank i Kredyt”, vol. 34, no. 4.

\section{Chiny - Ameryka Lacińska: stosunki gospodarcze w XXI wieku. Perspektywa latynoamerykańska dotycząca szans i zagrożeń}

\section{Streszczenie}

Artykuł porusza kwestię stosunków gospodarczych Chiny-Ameryka Łacińska w tym stuleciu. W ciągu pierwszych dwóch dekad XXI wieku nastąpił znaczny wzrost handlu między Chinami i Ameryką Łacińską, a inwestycje Chin w Ameryce Łacińskiej wzrosły. Chociaż prezentowany tekst omawia kwestie współpracy gospodarczej, jego głównym celem nie jest jednak prezentacja dynamiki tych stosunków, ale refleksja nad szansami i zagrożeniami dla Ameryki Łacińskiej wynikającymi ze współpracy gospodarczej między Chinami i Ameryką Łacińską. Artykuł omawia zatem możliwości i zagrożenia w wielu aspektach, podając różne argumenty i liczne przykłady. Wnioski z tego artykułu dotyczą zarówno pojawiających się wyzwań, jak i perspektyw współpracy.

Słowa kluczowe: Chiny-Ameryka Łacińska, stosunki gospodarcze, możliwości dla Ameryki Łacińskiej, zagrożenia dla Ameryki Łacińskiej 
